\title{
Self-Sacrifice and Care Ethics
}

\author{
Inge van Nistelrooij
}

\section{Introduction}

What if your close friend of many years asks if she can stay with you for a couple of weeks? What if she is suffering from cancer and her stay with you will be for a treatment in your town? I do not think many people would hesitate for a moment. At least Helen does not, when her friend Nicola turns to her in Helen Garner's novel The Spare Room. ${ }^{1}$ Nicola is not only suffering from bowel cancer, she is dying of it. But instead of facing what lies ahead, she flees from it into a ridiculous alternative therapy, forcing Helen (and others who compassionately surround her) to emotionally come to grips with her impending death while she herself denies it.

This story is about friendship and farewell, hope and denial, companionship and support, being alive and dying. But it is also a story about a caregiving friend, suffering from her friend's suffering and - although full of doubt as to whether she is entitled to rob her of her hope - seeking courage to confront her friend in her self-deception at the cost of truth, love and other people.

A touching story. I take it, however, as a starting point for thinking about those things that are the 'natural' setting of the story, that is, the sacrifices that Helen makes. The story of Abraham and Isaac teaches us that being prepared to making sacrifices may imply other sacrifices. No doubt Abraham is asked to sacrifice what is dearest to him, but implicitly Isaac is supposed to sacrifice his life without even being asked. It seems to me that this sacrificial entanglement sheds light upon the story of Helen and Nicola as well. Helen is willing to sacrifice time and energy, but how about the sacrifices her family has to bring?

First of all, Nicola requires much more care than expected. She is seriously ill and suffering day and night, with only an exceptional good hour or good day. Helen sacrifices her own physical well-being from the minute they meet at the airport. Within a few days she is exhausted. Washing and cleaning, day and night, cooking, driving, worrying, spending hours in waiting rooms and supporting her suffering friend, while suffering herself from what she sees as a

1 Helen Garner, The Spare Room (Edinburgh: Canongate, 2008). Helen is the novel's main character, and although there are similarities between her fictional life and Helen Garner's real life, the story is fiction. 
hopeless situation getting worse. Helen also sacrifices her family, being forced to suspend every contact with her daughter's family living next door, as they have caught a severe cold which is a major threat to Nicola's complete lack of resistance.

Helen puts her own life plans on hold, as caring for Nicola requires every bit of her energy; and Helen must also repress her own beliefs, as Nicola asks her to support her choice in favor of an alternative therapy and not to rob her of her last hope. Friendship in the end demands honesty, but when the air is cleared and the therapy is canceled, Helen still finds herself conforming to the wishes of Nicola in her final months. Caregiving entails accepting that in the end Nicola decides about the final stage of her life and affectionately submitting to her demands. In short, Helen's caregiving requires a great deal of sacrifice, almost to the point of sacrificing herself.

\section{Responsibilities in Caregiving}

This chapter examines self-sacrificial caregiving. Caregivers care for others, instead of sacrificing them. Abraham, being his son's caregiver, might have considered giving priority to his responsibility in that role and offered to sacrifice himself instead of his son. From the viewpoint of care ethics he should have. My point of departure is this emphasis of care ethics on the responsibilities in caregiving. I will focus on the self-sacrifice of the caregiver within the caring relation, as care ethics has a problem with engaging with the experience of caregivers sacrificing themselves. Although there are good reasons for being critical about self-sacrificial caregiving, I will argue that thinking about caregiving can be enriched by including thinking about self-sacrifice. In order to do so, we must reflect on the ambiguity of self-sacrificial caregiving: It is neither mere stupidity nor mere heroism. Therefore, I will take the experience of Helen in The Spare Room as one that raises questions about the relation between caregiving and self-sacrifice, specifically with regard to the distinct meanings and interpretations of sacrifice and self-sacrifice. I do not claim to interpret the book, nor do I use it as an illustration for a line of argumentation. Rather, I consider Helen's experience as one that challenges certain ideas about caregiving and reveals a more complex and ambiguous reality, which surfaces when we look at the sacrifices she makes.

This is not only Helen's experience, but can also be found in other literary works. I am thinking of the experience of the servant Gerasim, comforting his dying master by supporting his agonizing legs for hours night and day, in Leo 
Tolstoy's The Death of Ivan Ilyich; or John Bailey's experiences of the increasingly demanding care he gives to his wife, Iris Murdoch, as related in his books Iris: A Memoir of Iris Murdoch and Elegy for Iris: A Memoir. These books relate stories about the demanding care which the caregiver feels obliged to give out of compassion or love for the one needing care. These books, and many others like them, depict caregiving that requires a lot more than expected. Caregiving entails giving time, energy, sleep, health, well-being, and one's own relations. In doing so, the caregiver not only makes sacrifices, but also appreciates the essence of care. Strange as it may seem, these caregivers risk (at least) their health and happiness while simultaneously affirming themselves and realizing their own goals. In this article, I want to look at sacrificial caregiving on an everyday level in everyday circumstances.

\subsection{Aspects of Self-Sacrifice in Care}

Accepting the responsibility to care for another human being without considering the possible personal consequences - or maybe better, without having been able to consider them all beforehand - is an experience, I would like to defend, all-too familiar to caregivers. This experience gives rise to the thought that caregiving often takes place in an unavoidable tension between involvement and care for others, on the one hand, and self-care or self-preservation, on the other. This is well-acknowledged in care ethics but needs further exploration.

I take the term 'self-sacrifice' as a heuristic device for this exploration, as I think it illuminates exactly the point where the dynamics of care itself leads to giving up parts of ourselves, possibly even up to the point of sacrificing the self. Firstly, I will delineate how care ethics think about the costs of caregiving on the part of the caregiver, in order to further explore the difficulties of the tension. Then I will turn to theology, in which I offer a survey of the various meanings of self-sacrifice arranged in a taxonomy; I will also explore a distinction between what is and is not self-sacrifice. In a third part, I will return to the story of Helen. I will argue that care ethical thought is enriched by incorporating self-sacrifice in its various meanings.

The story, however, shows that there are three additional points. First, the suggested taxonomy needs to be extended, in order to include what was excluded, building on concepts of self-sacrifice from the spiritual and mystical traditions. Moreover, I will put the taxonomy of self-sacrifice itself into two dialectic tensions, each as a way of further deepening our understanding of care and sacrifice. In my conclusion, I will offer a definition of self-sacrifice in caregiving. 
The epistemological starting point of an ethics of care can be traced to the publication of In a Different Voice by psychologist Carol Gilligan in 1982. Gilligan, a student of Lawrence Kohlberg, proposes an ethics that takes into account the concrete responsibilities for concrete others, rather than an ethics formulated from an abstract and disconnected "point of view". ${ }^{2}$ A morality of care focuses on 'relationality' and the mature handling of responsibility claims. ${ }^{3}$ Gilligan speaks of the need to compromise that is felt by caregivers when facing conflicts between interests of the self and interests of the other. Only when a connection between integrity and care is discovered is one capable of mature care. Moreover, the identity of caregivers is defined by their relationships, responsibilities and care, rather than by their autonomy from others. ${ }^{4}$

From the start most care ethicists have been aware of the tensions involved in care and have discussed the question of asymmetry and equality. Those interested in Gilligan's findings take two opposing positions. On the one hand, researchers embrace her elaboration of a "feminine ethics". They ignore the aspect of power connected to care and gender roles, emphasizing the natural symbiosis of the caregiver (mother) and the care receiver (child), while making care a dyadic practice. A major representative of this essentialist view is Nel Noddings, who was one of the first to develop an ethics of care. ${ }^{5}$ She distinguishes between a natural moment and an ethical moment. The first is the natural feeling of 'engrossment', of being seized by the other person's need. This first moment may yield the ethical moment, when the caregiver actively accepts her responsibility for taking care. On the other hand, feminists advocate a disconnection of femininity and care, either by rejecting care ethics as an ethical perspective altogether, or by connecting care ethics to a power analysis and political ethics.

A major representative of this latter view is Joan Tronto, who defines care as:

[A] species activity that includes everything that we do to maintain, continue, and repair our 'world' so that we can live in it as well as possible.

2 Carol Gilligan, In a Different Voice (London: Harvard University Press, 1982).

3 Inge van Nistelrooij, Martha en Maria revisited. Zorg als ethisch perspectief (Tilburg: Tilburg University Press, 1996).

4 Gilligan, Different Voice, $156-160$.

5 Nel Noddings, Caring: A Feminine Approach to Ethics and Moral Education (Berkeley: University of California Press, 1984). Noddings does not use the term caregiver but 'one-caring'. 
That world includes our bodies, our selves, and our environment, all of which we seek to interweave in a complex, life-sustaining web. ${ }^{6}$

Her moral and political view of care involves an elaborate analysis of power inequalities in relations of care, on the levels of personal relationships, institutions, and the wider society. She considers care as a practice that not only builds relations but also builds society and orders relations in a political and institutional context. She concludes that, in many respects, taking responsibility for caregiving tasks involves assuming a subordinate, marginalized and powerless position, whereas pursuing power often involves the transfer of caregiving responsibilities to others. Tronto's plea is for a reallocation of the boundaries between a political and a moral view so that arguments from a care perspective can gain political impact.

\subsection{Responsibility and Power}

How do these lines of thought relate to self-sacrifice? Thinking of self-sacrifice in relation to care is difficult for various reasons. First, self-sacrifice in care is paradoxical. How could care entail self-sacrifice, as care aims at support, continuation, repair and maintenance? Would sacrificing the self not be the exact opposite of, and therefore incompatible with, the goals of care? Further, if one wants to take care of another person, the loss of self in sacrifice would simultaneously be the destruction of care and the end of the caring activity. Still, care involves commitment to the other who needs or deserves care because of his or her vulnerability or needs, or simply because he or she is loved.

Noddings and Tronto both consider the risk of sacrifice. Noddings understands the care relationship as a dyad, making the caregiver the sole source of care, and therefore can only see the risk of destruction of the caregiver, which she fiercely rejects. In order for care to be given as long as necessary, the caregiver must also take care of herself, upholding "the strength and beauty of her ideal (of being one-caring)." ${ }^{7}$ Her argument starts from the idea of caregiving itself, in which two persons want and need the caregiving to be continued. Obviously the one in need of care wants this, but the caregiver does so too, according to Noddings, for in caregiving the caregiver acts according to her moral conviction and accomplishes her moral ideal. In order to protect caregivers from self-sacrifice and exhaustion, there are instances in which they must 'quantitatively' reduce their ideal by excluding particular persons or groups in order "to maintain the quality of the ideal for remaining cared-fors." ${ }^{8}$ Tronto

6 Joan C. Tronto, Moral Boundaries (London: Routledge, 1993), 103.

7 Noddings, Caring, 105 .

8 Noddings, Caring, 114-115. 
frames care in a much broader constellation of social relations, institutions and politics, and rejects Noddings' dyadic structure; she thus acknowledges that care is other-directed and involves sacrifices.

However, there is power involved here too, and its distribution is inversely related to caregiving responsibilities. Those with power often are less inclined to make sacrifices, whereas those with little power often are inclined to give care, to give in, and to sacrifice even more.

Some people make greater sacrifices of themselves than do other people; some will even sacrifice too much. Part of this moral problem is exacerbated by the fact that those who are most likely to be too selfsacrificing are likely to be the relatively powerless in society. ${ }^{9}$

Hence, care ethicists have strong arguments against caregivers making sacrifices, most certainly against sacrificing themselves. Still, they acknowledge the tension within caregiving, when caregivers are engrossed by the other, experience compassion and love, and are more than willing to stand by the other and not abandon the one in need. Noddings' warning that an exhausted caregiver risks terminating care, and Tronto's warning that sacrificing entails a further marginalization and a relinquishing of the possibility of gaining power, make clear that sacrifices and self-sacrifice play a role in caregiving. It is paradoxical: Caregiving cannot do without sacrifices, even of the self, but it also should not be so. In order to gain clarity regarding this paradox, it seems helpful to make a semantic analysis.

\section{Self-Sacrifice from a Theological Point of View}

I now turn to theology, which not only has reflected on self-sacrifice for centuries, but can also help us with a clarification of terminology. What exactly do we mean by the ambiguous term self-sacrifice? ${ }^{10}$

Ruth E. Groenhout gives an extensive answer to this question in her analysis of kenosis, which is the Greek term for the self-emptying of God by becoming man in Jesus Christ." ${ }^{11}$ She understands kenosis as self-emptying, self-giving,

\footnotetext{
9 Tronto, Moral Boundaries, 141.

10 This question is asked by John Lippitt, "True Self-love and True Self-sacrifice," International Journal of Philosophy of Religion 66 (2009), 125-138.

11 Ruth Groenhout, "Kenosis and Feminist Theory," in Exploring Kenotic Christology: the Selfemptying of God, (ed. Stephen C. Evans; Oxford: Oxford University Press, 2006), 291-312.
} 
self-sacrifice. ${ }^{12}$ God in kenosis, however, did not stop being God. This is the leading idea in her analysis of self-sacrifice, which she opposes to self-destruction. She unfolds a taxonomy that is a sliding scale of distinct meanings of self-sacrifice:

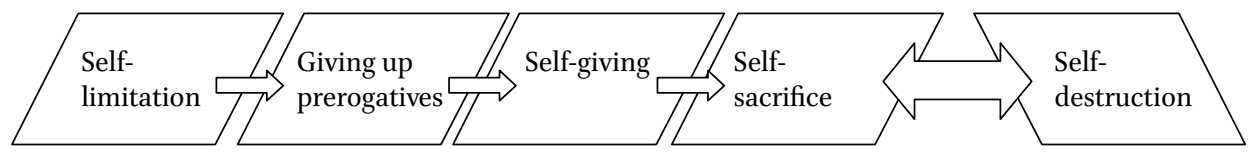

FIGURE 1 Groenhout's taxonomy of self-sacrifice.

Firstly, Groenhout explains the stages of self-sacrifice. Self-limitation is imposing limits on the self while also retaining "some sense of robust identity".13 Selflimitations that are imposed in the interest of others or of a higher good are close to kenosis.

The next stage is the giving up of prerogatives, when "a sense of a core self or identity is retained, but what is owed to that self is temporarily set aside". 14 (It hardly needs to be said that this is often the case in caregiving, as in the story of Helen.) Self-giving is next, which "implies some measure of giving up selfdetermination". ${ }^{15}$ Giving, in Groenhout's view, presupposes a recipient, and hence self-giving is other-directed, as the only possibility of giving the self to the other. ${ }^{16}$ The very next stage is self-sacrifice, which she describes as:

$[\mathrm{T}]$ he strongest term because it implies that in some significant way the self is actually lost. At a minimum it involves some sort of denial of the self, though this can be the denial of one part of the self for the sake of another part. At the maximum it involves what the phrase literally means - the sacrifice of the self, or of life. Further, in order for this to be a sacrifice (rather than, say, mere destruction) it also must involve giving up the self for some other person, or some other good. Self-sacrifice is the term I have focused on in this chapter [on kenosis] because it has connotations of giving more than just some aspect of the self - it suggests a giving up of the self itself, of giving up parts of one's identity. When the

\footnotetext{
12 Groenhout, "Kenosis," 291.

13 Groenhout, "Kenosis," 297.

14 Ibidem.

15 Groenhout, "Kenosis," 298.

16 Ibidem. I will refute this view later.
} 
parts of one's identity given up are central to one's sense of self, it may involve a loss of identity at some level. ${ }^{17}$

Secondly, Groenhout scrutinizes the distinction between self-sacrifice and mere self-destruction or self-annihilation. ${ }^{18}$ The distinction is in the telos (goal) of the action or practice: When one gives up "the self, or life itself, altogether, for some other person(s) or good", this is self-sacrifice. Self-annihilation and self-contempt fail the test. For self-sacrifice is the paradox of a self that not only sacrifices the self but also remains a self in this action of sacrificing. Therefore, according to Groenhout, a proper sense of self is fundamental for a proper understanding of self-sacrifice. This sense of self contains:

[A] sense that one is loved for one's own sake, that one's existence is a good thing, and that one can properly love the fact that one is alive and able to do things that are worth doing. ${ }^{19}$

These beliefs should be neither too strong nor altogether absent. Groenhout's conclusions are twofold. First, the self that is sacrificed must be recognized as a self with intrinsic value. Only a valued self that is emptied can be considered a sacrifice. ${ }^{20}$ Second, following from the first, a proper self-sacrifice is oriented towards the good, rather than a sacrifice of the self for its own sake. The latter is mere self-destruction..$^{21}$

\subsection{Kenosis, Caregiving, and Feminism}

Two more things need to be said about Groenhout's thoughts on self-sacrifice. First, she confronts kenotic thought of self-sacrifice with feminist theory. She is well aware of the extensive and valuable feminist critique of self-sacrifice, as for instance in Valerie Saiving's classic article The Human Situation: A Feminine $V_{i e w^{22}}$ However, she opposes the idea that feminism should reject the worth of sacrifice, for feminism has always been a movement fighting for a just cause, asking and inspiring women to sacrifice for this cause. And many women did sacrifice their happiness, according to Groenhout, fighting for this just cause. ${ }^{23}$

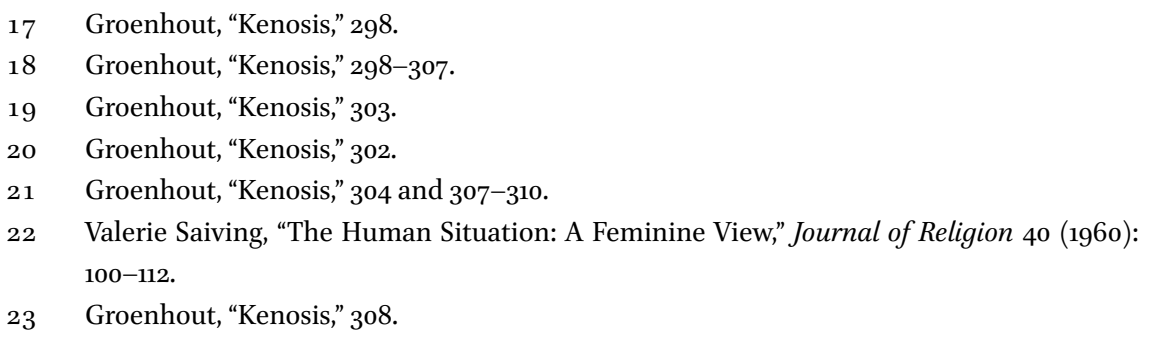


Feminist thought therefore can contribute to theological thinking by unveiling the harmful effects of the theological rhetoric of self-sacrifice, especially for women, and the ways in which Christians have misused sacrificial language in order to ask women to sacrifice themselves for inappropriate ends. ${ }^{24}$ However, when feminist theory concludes that self-sacrifice cannot be appropriate for women, it not only denies the feminist movement's history, in which self-sacrifice did take place, it also denies that women can be called upon to sacrifice themselves. This would be inappropriate for feminist thought itself, since it would be based on the assumption that women are weaker and less capable moral agents than men. ${ }^{25}$

Hence, the notion of self-sacrifice should not be rejected but must include an awareness of men and women sacrificing themselves for proper causes, on the one hand, and an awareness of the abusive and oppressive social systems (and, I might add, cultural expectations) that impede proper self-sacrifice, on the other. ${ }^{26}$

Put more strongly, unless one thinks that women's choices to sacrifice themselves for something appropriately important are justified, one runs the risk of denying women their own moral agency. ${ }^{27}$

A second addition to Groenhout's views comes from the English ethicist and philosopher of religion, John Lippitt, who has appropriated Groenhout's analysis as part of his study on "true self-love and true self-sacrifice". To the notion that self-sacrifice is based upon a sense of self-worth he adds the surprising suggestion that pride can be a virtue in self-sacrifice, despite the Christian and non-Christian rejection of pride. In his view, pride is not vanity but rather the same as self-respect. It is "a positive view of oneself [that] is necessary to live" and to be able to continue doing ethical work. ${ }^{28}$ It is a vital aspect of true selflove, which Lippitt considers crucial for other-relatedness. He refers to Paul Ricoeur who argued: "Must one not, in order to make oneself open, available, belong to oneself in a certain sense?"29 A sense of the self as worthy of love and respect is essential for understanding proper self-sacrifice. ${ }^{30}$

\footnotetext{
24 Groenhout, "Kenosis," 308.

25 Groenhout, "Kenosis," 309-310.

26 Groenhout, "Kenosis," 310-311.

27 Groenhout, “Kenosis," 311.

28 Lippitt, "Self-love and self-sacrifice," 135.

29 Lippitt, "Self-love and self-sacrifice," 136.

3o Lippitt, "Self-love and self-sacrifice," 136-137.
} 
Groenhout's taxonomy, considered in the previous section, offers us insight into the distinct meanings of self-sacrifice. We recognize them all in Helen's story, to which I now return. Helen indeed limited herself, gave up her prerogatives, gave herself, and sacrificed herself. At the same time, she valued herself, considered herself worthy of respect, when she defended herself and her beliefs against Nicola. She did not aim at destroying herself; rather she aimed at what she believed in, at what was of value: Their friendship and intimacy, especially during her friend's last months. Groenhout's sliding scale offers clear and plausible distinctions, not only between the possible gradations of self-sacrifice that determine the self's identity, but also between good and bad instances of self-sacrifice.

These clear distinctions, however, are challenged when we look a bit deeper at everyday experience. The ethical distinctions between right and wrong and between good and evil, both in literature and in life, often appear as simplifying reductions of reality. So, too, in Helen's story: While Groenhout's taxonomy is clarifying, it can also be shown to be insufficient.

In the next three parts, I will first propose to draw Groenhout's sliding scale differently and to extend it with a certain form of both self-loss and selfdestruction. In both the second and third parts, I will disclose a complexity of the scale as a whole, as it contains two tensions within itself. In the second part I will elaborate on the tension between violence and pride, and in the third part I will describe the tension between giving and receiving. These complicating additions to Groenhout's taxonomy have surfaced both from a consideration of Helen Garner's book and from my own research on self-sacrifice in caregiving.

\subsection{Extending Groenhout's Taxonomy to Self-Destruction}

Helen's story shows an expansion of demanding caregiving, starting with the offer of simple everyday help to a good friend in need and eventually leading to demanding caregiving and even self-sacrifice. Her care can be well characterized by Groenhout's taxonomy of self-sacrifice. Her telos is not self-destruction, as she values herself and the care she is providing. Throughout the story she learns to handle Nicola's demands, seeing them not as opposed to her own interest, but rather as a way of leading a different, giving life. The story portrays a formation process, a positive unfolding of a new (but perhaps also familiar) way of life, in which the self becomes more and more self-giving and self-emptying, while remaining a self.

At the same time, however, the story challenges this idea. Although we see how Helen tries to remain a self, giving expression to her exhaustion, 
defending her own needs and advocating her beliefs, there is also her commitment to Nicola and to caring for her. The situation is one she cannot control, as Nicola's need for care continuously pushes her to provide more and more care, beyond her limits. Helen's goal is to care for her dying friend, no matter what sacrifices this entails and despite the risk of losing the self, annihilating the self. Her commitment to Nicola, to their friendship, to care, is simultaneously a risk to herself. Only afterwards are we able to conclude that Helen, fortunately, remained a self. The goal of caring for Nicola could have led her to disregard her other telos, namely remaining a self, valuing the self. In fact, at times this is what caregivers do.

The question then is whether there can be a positive evaluation of self-loss, of selflessness, of self-effacing caregiving that is in line with self-sacrifice rather than opposed to it. Groenhout's sliding scale has a sharp-edged end, where self-sacrifice stops and is contrasted with the other practice, in which both the self of the caregiver was not valued and the practice was one of self-destruction. In view of the more complex reality in which aiming at a good might involve self-destruction and the forgetting of one's own value, I propose to redraw the sliding scale, based upon a tradition that Groenhout does not take into consideration. Mystical and spiritual traditions have displayed a different idea of identity, in which the self does not need to be preserved at all costs. Mystics have expressed a "highly dramatic" form of self-sacrifice, one that, in a certain sense, assigns positive value to self-destruction and the unworthiness of the self.

Starting from the everyday level, our sliding scale has the following stages: Self-limitation - giving of the self - self-abandonment (abandon) - selfdestruction (anéantissement).

'Self-limitation' takes place on an everyday, mundane level, involving minor sacrifices made in giving care. Caring for others requires the acceptance of less time for the self, of a limitation on one's autonomy. A tension begins to emerge between care for the self and self-loss, that is, the experience of limiting the self's activities, giving up hobbies, habits, needs. This is self-sacrifice on the most ordinary, daily level.

The next stage is the "giving of the self" to others or to an ideal in dedication, obliteration, abnegation or effacement of the self. Here persons come to mind

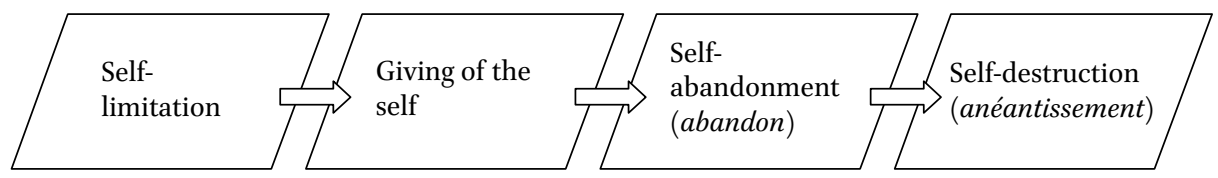

FIGURE 2 Extension of Groenhout's taxonomy of self-sacrifice. 
who care for someone or something with a strong sense of belonging, of loyalty and commitment, or of truthfulness, such as persons inspired by political, religious, social, juridical, scientific, or even sporting ideals.

The next two terms on the sliding scale are 'self-abandonment' (abandon) and 'self-destruction' (anéantissement). Both terms are defined in the Dictionnaire de spiritualité ascétique et mystique, which is my source here. ${ }^{31}$ 'Abandon' is a spiritual term for a state in which the soul either actively relies on (s'abandonner à) God or is passively abandoned by (être abandonnée par) God. In the active sense, the soul conforms itself to the will of God. The idea of abandon stems from the view that our spiritual life is the work of two: God and us. When we submit or conform to God's will, this is obedience, which is the normal means of reaching perfection.

However, this is not yet 'abandon', which requires an even more generous giving of the self, a form of conformity to the divine will proceeding from love. 'Abandon' is a total conformity, a complete renunciation of one's own will in order to embrace God's will. The source of the virtue of 'abandon' can be found in the Scriptures, in the teachings and examples of Jesus, culminating in the moments of his passion when he prays in the garden, "Father, if you are willing, remove this cup from me: Nevertheless not my will, but yours be done" (Luke 22:42) and when he falls beneath the Cross and prays, "Not as I will, but as you will" (Matt. 26:39).

Anéantissement is an expressive hyperbole that characterizes certain acts or states of the spiritual life. The term, however, should never be taken in an absolute sense. It expresses the supreme moral effort to diminish or eliminate the human self insofar as it opposes God, in all of its elements that block perfection. In worshipping God, the self expresses its unworthiness as a creature, symbolically obliterating the self and sacrificing it to God in a religious act of adoration. More perfect still is the passive form of anéantissement, in which the soul feels profoundly emptied and totally liberated by a powerful outward force. This mystical experience is described by Saint John of the Cross as a "dark night of the soul". It becomes a more or less permanent state, a path or special vocation, in which one's own will is given up while being mystically united with God. This experience of selflessness has also been expressed by the former UN Secretary General, Dag Hammarskjöld (1905-1961): "I am the vessel. The drink is God's. And God is the thirsty one". ${ }^{2}$

31 Marcel Viller SJ, Ferdinand Cavallera and André Derville, Dictionnaire de spiritualité et mystique: doctrine et histoire (Paris: Beauchesne, 1932-1995); "Abandon," 1-49; "Anéantissement," $560-565$. 
In searching for a sliding scale of self-sacrifice, for obvious reasons we are anxious to avoid the extremely violent and destructive forms. Mystical traditions, however, shed new (yet old) light on extreme forms of loss of self that do not oppose self-realization, but rather are a passive realization of the self, in a non-autonomous, radically dependent way. The value of the self is not denied but related to something or Someone greater than the self.

\subsection{The Tension of Violence and Pride}

Helen's story also gives rise to thought about the dimensions of violence, on the one hand, and pride, on the other. The scale of self-sacrifice itself exhibits a constant tension between pride and violence. Both are involved in caregiving, as shown in Helen's experience. One can rightfully say that Helen fulfills her gendered role as a mother and female caregiver submitting to cultural expectations of women that are oppressive and violent toward women, as they undermine their own life in the process. Yet there is also something else. During an exhausting night of endlessly remaking Nicola's bed (she is perspiring from pain, soaking the bed), Helen recalls her mother, who did the same for her when she was a child wetting her bed. She remembers her mother being able to remain patient, warm and loving, and she is very glad that she is able to care that way too. She feels that she is good at it. Lippitt's idea of pride as part of self-sacrifice can be recognized here. We must acknowledge, then, that violence (the harm to Helen's health), care (the alleviation of Nicola's distress), and pride (in Helen's performance) go together in Helen's experience.

Hence self-sacrifice stands in a tension. On the one hand, there is the inevitability of violence when living with and caring for others, requiring us to act on the other's behalf. On the other hand, there is the necessary affirmation of a self that is capable of doing good things, which is indispensable for any ethics.

As we have seen in Helen's story, caregiving is not all pleasure but also takes its toll. For instance, when Helen confronts Nicola with her honest concern that she is putting false hope in a dubious therapy, Helen is both violent, by destroying Nicola's hope against her explicit wish not to do so, and proud to have found the courage to end their dishonest concealment of reality, making a new intimacy possible in which they can face together what lies ahead.

Caregiving is a mixed experience, which cannot easily be divided into right and wrong. Both pride and violence are inevitable in real life, including in practices and relationships of caregiving. Caregivers are not always faithful to their ideal of caring, as described by Noddings. And when they give care they do not straightforwardly realize their ideal but also have to abandon other ideals, giving up wishes and needs, giving in and limiting their other plans. Giving care can be harmful to all involved; moreover, along with realizing goods, 


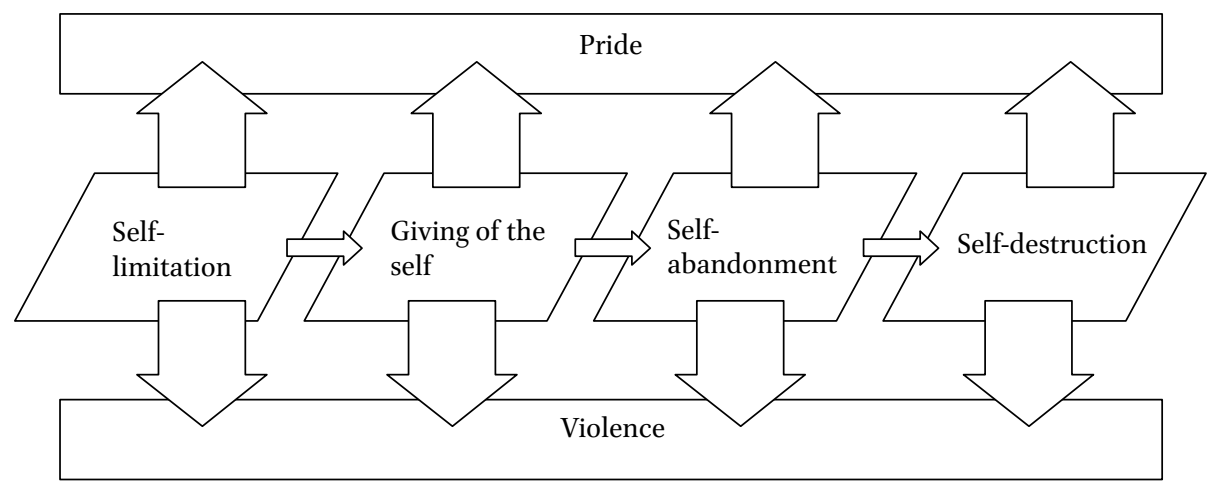

FIGURE 3 Self-sacrifice standing in the tension of violence and pride.

there often is unavoidable damage too. Things of value are cared for, nurtured and accomplished, but simultaneously other things of value are oppressed, neglected or rejected.

\subsection{The Trap of "Easy Heroism"}

In short, giving care is not unambiguous, and it cannot be reduced to "realizing a good". On the other hand, in giving care one does aim at a good, or rather one good among other goods. And when this good is realized, one can be proud of one's (part in the) accomplishment. This is everyday, small heroism in care. However, at this point Groenhout warns us against "easy heroism". She criticizes forms of idolatry in the case of caring for one's children. ${ }^{33}$ Many women, she argues, are lauded for devoting their lives to their children, and although she does not deny that this may be a high calling, she points out that it may also be a "spineless submission to whatever anyone else requests or demands of the agent". ${ }^{34}$ Feminist thinkers have rightly alerted us to this form of submission. The call to self-sacrifice may in fact be used as an excuse for failing to become capable of doing great things, and this evasion of higher activities often is made easier for women by societal expectations, according to Groenhout. 35

Along with this undue making of heroes out of everyday, unexceptional caregivers, we should also acknowledge that violent self-sacrifice is often socially and culturally expected and excused. Taking seriously the cultural expectations felt by women, we should think of self-sacrifice as social aggression as

33 Groenhout, "Kenosis," 310-311.

34 Groenhout, "Kenosis," 311.

35 Ibidem. 
well. Caregivers who provide demanding care do feel bound by expectations of what mothers, nurses, partners, friends, family, and neighbors (and among these especially women) do and should do. We should not discount the power of ideologies that have historically deprived women of their dignity, idealizing their physical suffering and self-abnegating behavior in favor of others (most often men) and religion. It is an image not only of self-abnegation, but also of social destruction through oppression, subordination, deprivation, and sexism.

\subsection{Self-Sacrifice in the Tension of Giving and Receiving}

Taking a final look at the story of Helen's care for Nicola, we want to add one more dimension to the sliding scale of self-sacrifice, namely that of giving and receiving. Groenhout has connected giving and receiving in self-sacrifice, arguing that in giving a recipient is presupposed. Again, reality is more complex. First of all, self-sacrifice is indeed giving, but giving has many meanings. And second, in many cases it may be that there is no receiving. At least we can say that in self-sacrifice and in care receiving is not guaranteed, neither as the receiving-care of the one needing care, nor as the receiving-back of the caregiver. And yet self-sacrifice and giving may have taken place.

Helen's story tells us about giving. She gives her home, her time and her energy to Nicola. She gives in, gives up, gives away and gives way to Nicola. She forgives her, and gives back to her what used to be and should continue to be valuable in their friendship. This does not mean that she does not receive. But first of all she gives, because that is both what Nicola needs and what Helen herself feels urged to do. She is not motivated by any prospective reward or return gift from Nicola. The care that Nicola has asked of Helen (and which turns out to be much more demanding than expected) is readily given, because Helen wants and is able to do so. Giving stands central, not an exchange or expected gifts in return.

This is an experience of caregiving. Someone or something needs care. Caregiving requires involvement and openness to the other, in order to see what constitutes care. Constitutive elements of care are not only needs but also what lends value to the friendship or relationship. One gives away what is of value to the self. What is not constitutive of care is what may be receivedin-return. There is no do ut des, not "I only give $\mathrm{X}$ when you give $\mathrm{Y}$ back to me". Receiving is not anticipated. It is not a condition for giving care; it is not constitutive of care itself.

Moreover, there may be a gift (of care) without it being actually received, and still there was a gift (of care). Helen, like other caregivers, sometimes experiences her care as given but not received. For example, she spends her time and money on special meals for Nicola, which turn out to be given in vain 
when Nicola is too ill to eat. This, however, does not erase the gift. The giving was in the meal, in the care devoted to preparing it, so that Nicola could have eaten, if she had wanted to. Hence a gift may be given without there being a recipient. We see that, for instance, when we give money to charity or when we save money for the future studies of our children or for our pensions. The recipient is distant, either in space or in time, and may or may not be a recipient in the end. This does not mean that nothing is given: There was a gift, or even a sacrifice. And in this sacrifice something of value was given, or given up, for something which the giver or the one sacrificing holds to be sacred, sometimes even without taking into account whether or not it is received.

An example may be helpful here, of one sacrificing himself for a good without it being received. This example is Father Maximilian Kolbe, who volunteered to die in place of somebody else in Auschwitz. ${ }^{36}$ He must have seen the ambiguity of his deed. He was not rescuing anybody, as everybody in the concentration camp would eventually be killed anyway, and he was not changing any system for the better. Nazism would not change because of his choice, nor would there be political implications. And yet, he realized a good by giving his life. There was no receiving of this gift; the man whose place he took did not receive his life, but only a bit more time. Still, Kolbe gave his life. Was it in vain? Practically speaking: Yes. We can sense the value of his action nonetheless.

This does not mean, however, that there cannot be receiving in care. There certainly can be, including in the story of Helen and Nicola. When giving care, one unexpectedly may receive the other, or one's (better) self, or contact, community, grace, love... As a nurse in a home for the elderly once expressed her definition of care: "Giving care is sharing intimacy", while another nurse said: "Giving care is being there for the resident without him needing to be grateful". ${ }^{37}$ These remarks show the fragility of the relationship, which may, but also may not, be one of giving and receiving.

We may conclude, therefore, that self-sacrifice is pure giving. If a return is required, then the character of sacrifice is erased. A return, if there is one, can only be gratuitous. This is what is rightly expressed by the term 'sacrifice', in which something of value to the self, or even the self itself, is given, given up, given away. Therefore, in our figure, receiving care is not part of the figure of self-sacrifice. It is not a required element, but rather an unexpected, hoped-for grace.

\footnotetext{
36 See http://en.wikipedia.org/wiki/Maximilian_Kolbe.

37 Inge van Nistelrooij, Zorgen doe je samen (Heeswijk: Uitgeverij Abdij van Berne, 2009), 12 and 17.
} 


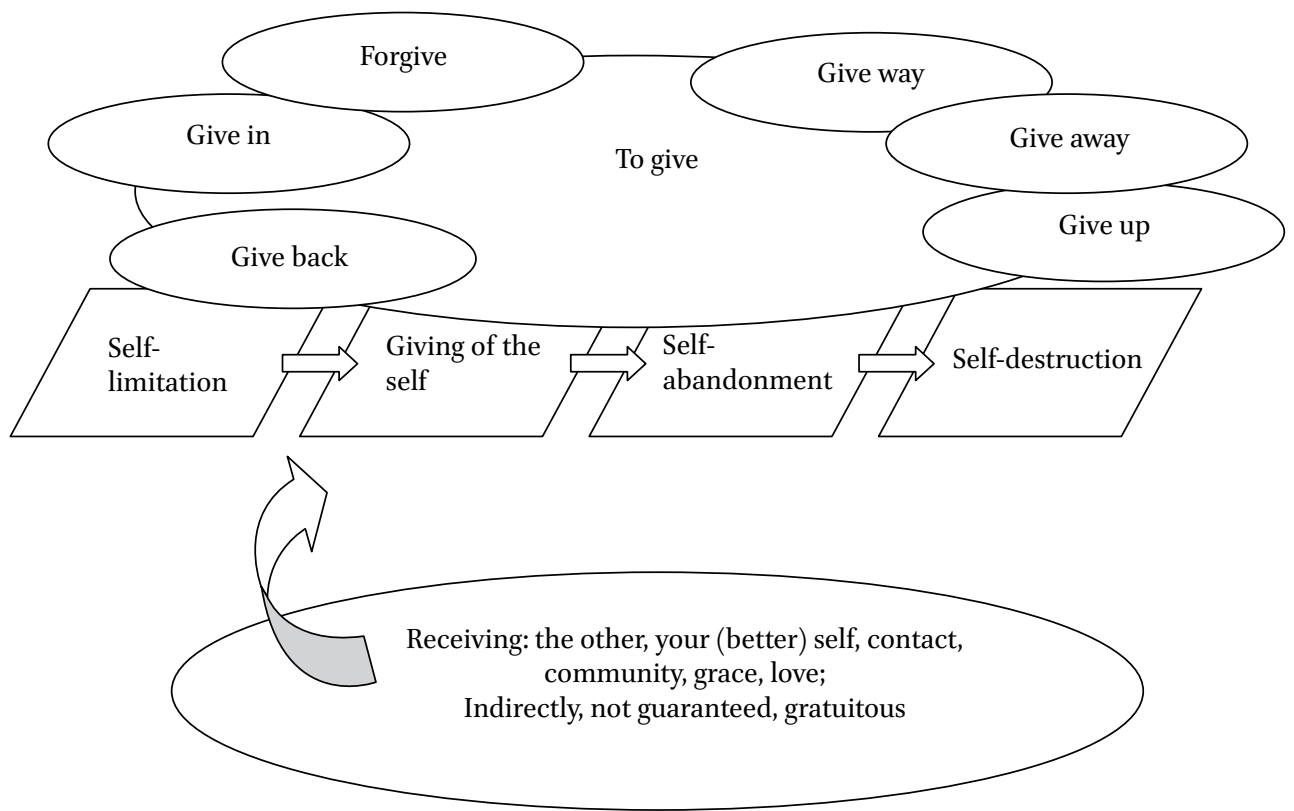

FIGURE 4 Self-sacrifice as giving without presupposing receiving.

\section{Conclusion: Thinking of Care from a View of Self-Sacrifice}

In the light of the semantic analysis we may define self-sacrifice in caregiving as follows. Self-sacrificial care is care that the self is determined to give because of the good realized in this specific act of caring, despite the acknowledgment by the self that one will not realize other goods (for instance, care for the self), and despite the acknowledgment that the good of this caring is not unambiguous or indisputable. In the latter case, for instance, the one cared-for may not be very much loved, or may not be indubitably deserving care; or the caring activity may be the caregiver's pitfall; or the caregiver may be exhausted.

When thinking about self-sacrifice in care, we must always be aware of the proper and improper forms of self-sacrifice. The caregiver's dignity is at stake, both when the caregiver does not aim "high enough", evading his or her capabilities and responsibilities, and when a caregiver seeks submission or selfdestruction. This is not merely a personal decision but is always mixed with cultural, societal and religious systems as well as images and language that reflect social distribution of power and positions.

Throughout the present analysis we have gained a view of the self as fundamentally permeable, not self-determining, but affirming itself (sometimes 
with pride!) while receiving all that is given in his or her existence as well as existence itself. As in the experience of Helen, the self cannot be understood as living and shaping its life by itself alone but only as living a life given by grace, that is, as a gift and a task that one may fulfill with pride. Helen would not be Helen, would not be realizing herself, if she did not respond to Nicola's needs. But she did respond, even before she could decide to do so or could determine the amount of time and energy she would spend. Self-sacrifice serves as an adequate heuristic device to show the contingency and "tragic edge" 38 that should always be incorporated in our understanding of care.

38 Groenhout, “Kenosis," 305. 